\section{A Fugue in Cycles and Bels}

By John Mills. Pp. vii +269 . (London : Chapman and Hall, Ltd., 1936.) 13s. $6 d$. net.

THE author points out that music in past ages has developed "without benefit of physics, except in so far as the simple rules of Pythagoras gave support to certain musical intervals against possible changes in taste, or style . . ." In this book an account is given of modern developments arising from successful efforts to improve the transmission of music and speech. The two chief factors are pitch and frequency, the latter here denoted in the title as cycles; and intensity and loudness, indicated by 'bels'. If one sound is ten times as loud as another, it is one 'bel' higher in sound level. If $A$ is about 25 per cent louder than $B$, then $A$ is one 'decibel' (db.) above $B$. The necessity for some such scheme arises from the fact that a full orchestra may vary in sound energy from about 70 watts down to a few microwatts, with a ratio of ten million to one, so that a logarithmic notation is required, and in this particular case the range is clearly 7 bels, or 70 decibels.

Although in most cases frequency and pitch may be deemed equivalent, yet an increase of intensity, without change of frequency, will produce an alteration of pitch. Thus it is stated (p. 117) that Stevens of Harvard has found that "if the power-level of a 150 cycle tone, as it reaches the ear, is $76 \mathrm{db}$. the frequency of the reference tone has to be reduced to 145 cycles (at a low power) to be equal in pitch". The latest determination of the threshold of audition is stated (p. 85) to be $10^{-16}$ watts. This extreme sensitivity of the ear and mind is combined with marvellous delicacy of analysis.

The book also deals in an interesting way with questions of transmission, distortion, overloading, noise, reverberation and auditorium acoustics. The final part presents and explains plots and graphs obtained mainly at the Bell Research Laboratories, New York.

\section{The Book of Minerals}

By Alfred C. Hawkins. Pp. xii + 161. (New York : John Wiley and Sons, Inc.; London : Chapman and Hall, Ltd., 1935.) 7s. $6 d$. net.

THE professed purpose of this little book is "to tell to the people the story of the minerals", and to this end the author has been careful to keep his text free from all technicalities. The opening section offers brief advice on where to look for minerals and how to collect them, "how to tell minerals apart" (by means of hardness, specific gravity, blowpipe tests, etc.), and gives some account of crystals and their classification. The main part of the book contains short descriptions of the most common minerals, well illustrated with photographs of museum specimens.

To one knowing nothing of the subject "The Book of Minerals" would provide a pleasant companion for a walk round a museum collection. The young collector, for whom in many ways the book seems to be designed, would soon reach a stage when this "Mineralogy without Tears" would no longer satisfy his growing thirst for knowledge.

\section{Tabulæ Biologicæ Periodicæ}

Herausgegeben von C. Oppenheimer und L. Pincussen. Band 3, Nr. 4 (=Tabulæ Biologicæ, Band 9, Nr. 4). Pp. iv +321-436. Band 3, complete, 55 gold marks. Band 4, Nr. 1 (=Tabulæ Biologicæ, Band 10, Nr. 1). Pp. 160. Band 4, complete, 55 gold marks. Band 4, Nr. 2-3. (=Tabulæ Biologicæ, Band 10, Nr. 2-3.) Pp. 161-208; 209-288. (Den Haag : W. Junk, 1934.) 55 gold marks.

THe data given in these numbers of the "Tabulæ Biologicæ" will be of interest to all biologists. The last part of vol. 3 concludes the list of polypeptides acted upon by erepsin and trypsin, and also tabulates the compounds hydrolysed by various amidases. The remainder of the number is devoted to a list of plants cultivated for their food or of commercial value, including their natural habitat, centres of cultivation, use and finally chromosome number. An index to the volume is included.

The first part of vol. 4 has sections dealing with redox-systems, respiratory pigments and the blood groups of the different nations of the world (which is concluded in No. 2 of the volume). Other sections deal with the influence of light on the germination of seeds and the physiology of the Myriapoda. No. 2 also includes data on the kidneys and a list of acids found in lichens. No. 3 has three sections only : a list of the less common elements found in the tissues of different animals ; data on the skulls of prehistoric man and finally a second article on the biology and toxicology of gases, vapours and sprays used in warfare. The material of this journal does not lend itself to a more detailed review, but the data should prove extremely useful for those interested.

\section{Probability and Random Errors}

By Dr. W. N. Bond. Pp. viii +14l. (London: Edward Arnold and Co., 1935.) 10s. 6d. net.

THIs is a bright and original treatment of a subject voted by many as dull, however necessary it may be for the experimentalist to discuss with care the accuracy of the end result of his measurements and calculations. The book is addressed primarily to students of physics and chemistry, but others will find it interesting and useful. It begins with questions of pure probability, leading up to the discussion of problems of random migration and kindred topics that are of interest to the modern physicist. Various types of error are listed, and a chapter is devoted to their estimation. We then have an unusually full chapter giving the probable errors of various combinations of measured quantities. The fitting to data of the straight line and parabola is described, together with examples of the fitting of other types of curves. The first part of this section might have been simplified arithmetically, since the data are in all cases equally spaced, by giving a method, such as that of Aitken, based on orthogonal polynomials. A chapter on periodogram analysis follows, and the book ends with a number of miscellaneous examples, and with two short appendixes, in one of which the formulæ of the book are conveniently summarised for reference. 